This is the pre-print version of the following article: Foster, C. \& Heeks, R. "Conceptualising Inclusive Innovation: Modifying Systems of Innovation Frameworks to Understand Diffusion of New Technology to Low-Income Consumers", European Journal of Development Research, 25(3), 333-355, 2013 which has been published in final form at:

http://www.palgravejournals.com/ejdr/journal/vaop/ncurrent/full/ejdr20137a.html

\title{
Conceptualising Inclusive Innovation: Modifying Systems of Innovation Frameworks to Understand Diffusion of New Technology to Low-Income Consumers
}

\section{Christopher Foster and Richard Heeks*}

${ }^{*}$ Corresponding Author. Centre for Development Informatics, IDPM, Arthur Lewis Building, University of Manchester, M13 9PL, UK

Phone: +44-161-275-2870; Fax: +44-161-275-2898

Email: richard.heeks@manchester.ac.uk

\begin{abstract}
Inclusive innovation is the means by which new goods and services are developed for the billions around the world living on lowest incomes. Although a topic of increasing interest, it has been relatively underresearched and under-conceptualised to date. This paper studies arguably the most successful new technology to reach low-income groups: the mobile phone, focusing specifically on its diffusion in Kenya.

Systems of innovation are shown to be an appropriate frame for conceptualisation of inclusive innovation. However, the conventional content of this framework must be modified to allow for particular features of inclusive innovation, including the nature of innovations required, the actors involved and their inter-relations, the type of learning they undertake, and the institutional environment in which they operate. Four domains of that system are identified as needing to be effective if inclusive innovation is to succeed: relating to the product, its retailing and support, the micro-enterprises that provide these demand-side services, and the wider context.
\end{abstract}

Keywords: inclusive innovation; systems of innovation; mobile phones; bottomof-the-pyramid 


\section{Introduction}

A new form of innovation is growing in developing countries. As often with new phenomena it has different names that reflect different emphases: "inclusive innovation", "pro-poor innovation", "below-the-radar innovation", "BoP [bottom of the pyramid] innovation" and more (Horton, 2008; Kaplinsky et al., 2009; Joseph et al., 2011). But its core focus is the structures and processes required to develop and deliver innovative technologies (goods and services) for poor consumers. While readily connected to the ideas of Fritz Schumacher and the concept of appropriate technology, it has novel features including significant involvement of the private sector and global value chains, the development of poor consumers as an accessible mass market, growth of technological capabilities within developing countries, and the involvement of new technologies (Kaplinsky, 2011; Cozzens and Sutz, 2012).

How are we to understand this new form of innovation? Systems of innovation (Sol) frameworks would be an obvious point of departure. Sol approaches are now firmly established in the literature as an evidence-based means to understand innovation. They are grounded in a systematic understanding of innovation processes, actors and relations, and are at the core of policy construction to drive national innovation (Lundvall, 1992a; Freeman, 1995; Edquist, 1997). In developing countries, Sol frameworks have been used to analyse innovation, particularly examining the structures and policy by which nascent industrial sectors might be beneficially linked into processes of globalisation (Lundvall and Intarakumnerd, 2006; Lundvall et al., 2009a).

A number of authors have identified the potential relevance of systems of innovation concepts for understanding innovation for the poor in developing countries (e.g. Mackintosh et al., 2007; Altenburg, 2009; Kraemer-Mbula and Wamae, 2010a). Others have shown the potential for Sol ideas to be extended to encompass some of informal structures and processes typical of poor communities (e.g. Chaminade et al., 2009; Ratanawaraha, 2012). However, as yet there has been a lack of field data-based application of these ideas, to systematically understand whether standard Sol ideas are applicable or whether the particular features of innovation for the poor would require us to modify these ideas. Thus, in this paper - drawing on the case of mobile handset supply in Kenya - we examine the compatibility of systems of innovation approaches with what we will term "inclusive innovation"; that is, processes of innovation that specifically encompass those on lowest incomes.

We find that the core components and core focus of systems of innovation are well suited to understanding the overall nature of inclusive innovation. However, in its conventional form Sol underplays certain features of inclusive innovation such as processes of technology diffusion, informal demand-side actors and intermediaries, and the role of localised and informal institutions. Our overall contribution, then, is to deepen the conceptualisation of inclusive innovation, and to broaden the demonstrated applicability of systems of innovation frameworks. 
The paper is organised as follows. In Section 2, we take a systematic approach to compare the contents of conventional systems of innovation with what is known from the literature about inclusive innovation. Section 3 introduces the case of mobile phone handset delivery in Kenya, which in section 4 is more deeply examined from an innovation perspective. In section 5 , we demonstrate that a focus on inclusive innovation requires the incorporation into Sol of new analytical constituents - incremental innovation and inclusive intermediary actors, relations and institutions. These are summarised more generally in Section 6 , both confirming but also extending the literature-based analysis provided earlier.

\section{Conceptualising Inclusive Innovation}

\subsection{Inclusive Innovation and "Innofusion"}

Traditionally, and still dominantly, innovation and innovation policy in developing countries have been associated with large formal organisations in the public or private sector, often addressing export markets or producing goods (rarely services) for higher-income local consumers which have little connection or relevance to the low-income majority of the population (Mytelka, 2000; Kraemer-Mbula and Wamae, 2010b; Fu et al., 2011). There is, though, growing innovation for that latter group, associated - as noted above - with a variety of terminologies.

Here, we work with the notion of "inclusive innovation", which is the particular subject of research and debate (IDRC, 2011). Conventional views of innovation (often implicitly) understand development as generalised economic growth. By contrast, inclusive innovation explicitly conceives development in terms of active inclusion of those who are excluded from the mainstream of development. Differing in its foundational view of development, inclusive innovation therefore refers to the inclusion within some aspect of innovation of groups who are currently marginalised (ibid.). As in this paper, the group mostoften identified is those on lowest incomes (e.g. less than US\$1 or US\$2 per day) but women, youth, the disabled, and ethnic minorities may also be the focus for concern (Codagnone, 2009).

Within the literature, one finds four aspects of inclusivity that are highlighted (Utz and Dahlman, 2007; Altenburg, 2009; Cozzens and Sutz, 2012):

- Inclusivity of innovation precursors: e.g. that problems to be addressed by innovation are of relevance to the poor.

- Inclusivity of innovation processes: e.g. that the poor are involved in the development of innovative goods and services.

- Inclusivity of innovation adoption: e.g. that poor consumers have the capabilities to absorb innovations.

- Inclusivity of innovation impacts: e.g. that innovative goods and services have a beneficial effect on the livelihoods of the poor.

Definitions of inclusive innovation would require one or more of these four criteria to be met, and so they subject innovation to a judgemental scrutiny that 
is absent in conventional understandings. Such judgements typically require a micro-level concern with the livelihoods of marginalised groups (Joseph, 2012), which may be contrasted with the macro-level (national, regional, sectoral) analysis usually found in conventional approaches (Edquist, 2005).

Any one of the four aspects of inclusivity would provide the basis for a research paper. Our own selected focus relates to all four of these concerns and is an issue that has somewhat "fallen between the cracks" in discussion of inclusive innovation to date: the process of technological diffusion by which an alreadydeveloped technology comes to be widely available to poor consumers in developing countries.

According to linear models of innovation, there is a clear separation between processes of innovation, of production, of diffusion. Despite their resilience, such models have long-since been debunked as bearing little relation to the realities of innovation (Fleck, 1993). Processes of production, distribution and implementation are not separable, and they all involve continuous innovation and feedback. Hence Fleck's use of the term "innofusion" to cover the process of bringing inventions into use: as an innovated good or service is diffused, further innovations are required both to the good/service but also in surrounding social systems, and feedback from that diffusion leads to further innovation in the original good/service. Innovation and diffusion are thus inextricably intertwined.

Our interest could therefore be called "inclusive innofusion": what has to date been rather a missing link between a new invention and its widespread adoption by low-income consumers. How does this aspect of the innovation process help inclusive goods and services become pervasive, and how can we conceptualise this process? Our starting point will be the literature on systems of innovation.

\subsection{Systems of Innovation}

Systems of innovation is less a narrow body of theory than a way of understanding innovation as a system of structure and process (see example in Figure 1, OECD, 1999:23). Structurally, innovation is seen to emerge from a broad network of dynamically-linked actors which exist within an institutional context (Edquist, 2005). Through "an ongoing process of learning, searching and exploring" this system generates new knowledge and, hence, innovation (Lundvall, 1992b:8). 


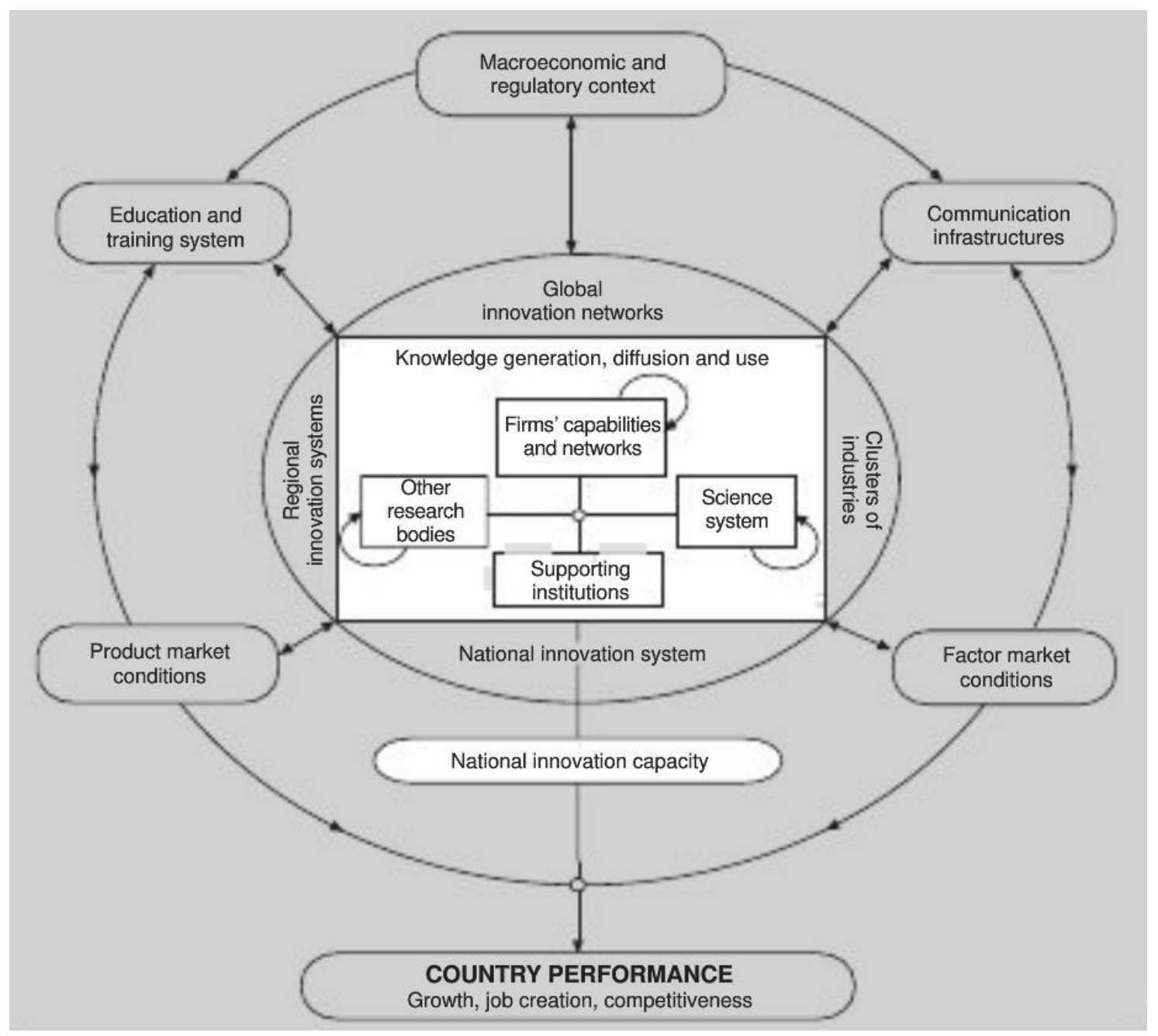

Figure 1: Example systems of innovation conceptualisation

Systems of innovation frameworks have proven better than prior models at explaining the experiences of late-industrialising nations, which were found to have developed not via an R\&D policy focus but by aligning and integrating multiple interconnected parts of the economy, guiding processes of iterative innovation and technological learning (Bell and Pavitt, 1993; Mathews and Cho, 2000). These frameworks have also been used to analyse and guide innovation policy in developing countries; notably in seeking to accelerate industrial sectors into wider global circuits (Lundvall and Intarakumnerd, 2006; Lundvall et al., 2009a).

Demonstrating the relevance of Sol to developing countries does not, though, mean that it is necessarily applicable "as is" to inclusive innovation for the poor. Indeed, work in the informal sector suggests conventional Sol ideas may well not be "as is" applicable (Müller, 2010). However, there has not yet been a full, direct and systematic investigation of Sol's applicability to inclusive innovation. The questions have thus been raised: how relevant is Sol to inclusive innovation, does it need to be modified and, if so, how (Mackintosh et al., 2007; Cozzens and Sutz, 2012). 
To address these questions, and before presenting the case study evidence, we will first examine what is already known from the literature. We will do this by analysing conventional systems of innovation ideas through the five core structure and process components identified above: innovation, actors, learning, relations, and institutions. We will compare this with what is already known about inclusive innovation. This provides a foundation of existing knowledge which the case study will seek to test and, if appropriate, build upon.

\subsection{Actors and Innovation}

Following the traditional interests of innovation studies, systems of innovation frameworks have conventionally focused on identifiably-located, large, formal organisations on the supply side as represented in Figure 1, working on formalised and technical research and development that is often supply-driven. But looking at studies of inclusive innovation in developing countries, we see a greater emphasis on non-traditional, demand-side innovators. This includes informal sector workers (King, 1996; Nichter and Goldmark, 2009) and lead users (O'Farrell, 2003; Cheneau-Loquay, 2010) who are incrementally innovating to adapt new technologies to the needs and circumstances of local consumers.

In some cases, Sol has extended its conception of innovation actors, for example, to incorporate innovation intermediaries who stand between original suppliers and final consumers (Howells, 2006; Stewart and Hyysalo, 2008). They are mainly conceived as information/knowledge brokers, typically connecting to formal research and development organisations (Winch and Courtney, 2007).

Non-Sol-based work has shown the importance of such intermediaries in reaching bottom-of-the-pyramid markets but not quite in this R\&D broker role (London and Hart, 2004). These intermediaries are themselves innovators with their adaptive, incremental innovations needed because of the frequent mismatch between externally-designed innovations and the particular environment of heterogeneous groups of poor consumers. And - building on Fleck's point noted already - we could call them "innofusion intermediaries"; recognising they may need to innovate not just the core technology in order to help diffusion, but also the mechanisms of that diffusion.

Sol frameworks may therefore encompass a broad range of innovation actors as inclusive innovation would require. But we need to supplement that theoretical potential with more specific detail: about who exactly the actors are in practice; how they connect to the supply and demand side of the system; and what the systemic contribution of their innovative activity is.

\subsection{Learning and Relations}

Systems of innovation describe the interactivity of system actors; specifically how changing relations and modes of learning within the system will orientate innovation over time (Lundvall, 1992a). Innovation is seen to emerge through various categories of learning: learning-by-doing, as individuals build knowledge by engaging in production processes; learning-by-using, where learning relates to the adjustment that actors must make to ensure that new 
technologies fit particular tasks; and learning-by-interaction, where learning comes from working with other system actors.

Experiences of inclusive innovation suggest that this form of learning is central to serving low-income markets, and that Sol could thus be a relevant framework (Kraemer-Mbula and Wamae, 2010b). However, the Sol focus has tended to be on learning by doing about the direct production and implementation of technological artefacts. This is somewhat different from learning about diffusion or, more generally, about the wider social processes that surround the distribution and use of new goods and services in poor communities.

Other critiques of Sol also seem potentially relevant to the context of inclusive innovation - that there is an assumed coherence and systemic instrumentality about all forms of learning; they are seen solely within the context of the system, and to act in the interests of the system, which might typically be profitmaximisation (Edquist and Johnson, 1995).

It is recognised that relations between actors in the innovation system play a key role in determining how these different learning dynamics play out (Lundvall, 1992a; Edquist, 2001). It is the assumption that more formalised, tight relations between actors will result in a more guided and coherent innovation system, whereas loose relations might allow more flexibility but may also lead to higher costs and higher risks (DeBresson and Amesse, 1991). We have seen that flexibility which allows innovators to meet the needs of specific local markets is an integral part of successful inclusive innovation. Yet other literature argues close relationships (e.g. via co-production/co-creation) are better when seeking to deliver new goods and services for the poor under conditions of uncertainty (Foster and Heeks, 2010). Thus, it is unclear how relationships should best be configured for inclusive innovation.

Again, therefore, the general concepts of systems of innovation seem relevant to inclusive innovation, but some specific issues require further investigation. We would like to have a clearer picture of the types of relationships that intermediaries build when serving low-income markets, how they link to other system actors, and what this means for learning and system performance.

\subsection{Institutions}

In its general use in systems of innovation, "institution" has been rather a fuzzy term, not least due to its use covering both the neo-institutionalist sense of a constraint on behaviour and also the more lay sense of being synonymous with "organisation" or groups of organisations (Edquist, 1997). Whichever the use, though, the emphasis has been on formality: formal rules and regulations, and formal bodies which are seen to provide a relatively stable context that directly guides - and ideally enhances - the actions of innovation system actors (Johnson, 1992). The focus of attention has been to understand how the right combination of formal institutions - policy especially - can service to orient the innovation systems towards economic growth (North, 2009). 
Using this yardstick, developing countries may be decried because of their lack of formal institutions of relevance to innovation (Utz and Dahlman, 2007). But a consideration of inclusive innovation would need to go further than this. It would need to recognise that formal institutional forces may be present in theory but not in practice at the local level, with either absence or transgression often being the norm (Brinkerhoff and Goldsmith, 2005). It would also need to recognise informal institutions: understood as the behavioural norms embedded within local social relations that are endogenously enforced rather than exogenously imposed (Shirley, 2008). These may be more important guides to micro-level activity, having been shown critical within inclusive innovation (Matin et al., 2002). Yet conventional Sol has been rather poor at encompassing these aspects of institutions (Altenburg, 2009).

A systems of innovation approach would therefore recognise the importance of institutions for inclusive innovation, but it leaves room for further examination of the full nature of those institutions as they impact upon innovation intermediaries serving low-income markets.

\subsection{Inclusive Innovation Issues from the Literature}

Systems of innovation is a high-level and flexible framework that can be resolved to a few core systemic components. Our review of literature summarised in Table 1 - suggests that those components, as categories, may be relevant in understanding inclusive innovation. But that the content of conventional Sol thinking mismatches what we already know about inclusive innovation.

\begin{tabular}{|c|c|c|}
\hline & $\begin{array}{l}\text { Conventional Systems of } \\
\text { Innovation }\end{array}$ & $\begin{array}{l}\text { Inclusive Innovation Issues from } \\
\text { Literature }\end{array}$ \\
\hline $\begin{array}{l}\text { Overall } \\
\text { Scope }\end{array}$ & $\begin{array}{l}\text { Development as economic growth } \\
\text { - Macro-level analysis }\end{array}$ & $\begin{array}{l}\text { Development as socio-economic } \\
\text { inclusion } \\
\text { - Micro-level analysis of livelihoods }\end{array}$ \\
\hline \multicolumn{3}{|c|}{ Structure and Process Components } \\
\hline Innovation & $\begin{array}{l}\text { Located innovation pre-, durante- } \\
\text { and post-production } \\
\text { - Growth-oriented innovation } \\
\text { - Supply-driven innovation } \\
\text { - Technical innovation }\end{array}$ & $\begin{array}{l}\text { Incremental innovation with a focus on } \\
\text { diffusion processes } \\
\text { - Local needs-oriented innovation } \\
\text { - Demand-driven innovation } \\
\text { - Non-technical innovation }\end{array}$ \\
\hline Actors & $\begin{array}{l}\text { Main focus on: } \\
\text { - Higher-income markets/consumers } \\
\text { - Formal supply-side organisations } \\
\text { in industrial sectors } \\
\text { - Innovation intermediaries as R\&D } \\
\text { brokers }\end{array}$ & $\begin{array}{l}\text { Main focus on: } \\
\text { - Low-income consumers } \\
\text { - Non-traditional, informal, demand-side } \\
\text { innovators } \\
\text { - Innofusion intermediaries }\end{array}$ \\
\hline Learning & $\begin{array}{l}\text { Learning by doing plus using and } \\
\text { interacting: } \\
\text { - Learning about production and } \\
\text { implementation } \\
\text { - Learning about technology } \\
\text { - Coherence and profit-maximisation } \\
\text { as guides }\end{array}$ & $\begin{array}{l}\text { Some form of DUI learning } \\
\text { - Learning about diffusion and use } \\
\text { - Learning about wider social processes }\end{array}$ \\
\hline Relations & Formal, close relations preference & $\begin{array}{l}\text { Value of both close and loose, flexible } \\
\text { relations }\end{array}$ \\
\hline Institutions & $\begin{array}{l}\text { Formalised, relatively-static, direct- } \\
\text { impact overarching institutions }\end{array}$ & $\begin{array}{l}\text { Shortfall of formal rules in practice, and } \\
\text { importance of informal institutions at }\end{array}$ \\
\hline
\end{tabular}


Table 1: Literature-Based Inclusive Innovation Issues Differing from Conventional Sol Models

It would be not be appropriate to categorise all Sol literature under the "conventional" banner. Work has been ongoing both to develop Sol and to apply it to an ever-greater range of innovations. One result - particularly, though not exclusively, from work based on developing countries - has been a broadening of the content within particular components; a broadening which takes application of Sol closer to the nature of inclusive innovation. Examples include:

- Incorporation of demand-side actors such as those working directly with or for final consumers (Edquist and Hommen, 1999).

- Acknowledgement that innovation is not just located in formal organisations such as R\&D units or universities (Lundvall et al., 2009b), including identification of informal sector actors as innovators (Müller, 2010).

- Inclusion of informal intermediaries that assist in the diffusion of innovations (Poncet et al., 2010).

- Integration of learning that is oriented more to social then technological issues (Ratanawaraha, 2012).

In general, these reflect piecemeal modifications to Sol, but they suggest a possible continuum of Sol application and a direction of travel that could lead to incorporation of inclusive innovation. Our task is to continue that journey and push further via a systematic exploration around each of the identified Sol components, seeking to explain in detail the specific features of inclusive innovation.

In the remainder of this paper, we will therefore instantiate the content of Table 1 , seeking to confirm or otherwise the issues already raised in the literature and analysing whether or not they need to be further modified. We do this by drawing on a case study of inclusive innovation in a developing country; more specifically by drawing on a case study of "inclusive innofusion", that traces the process that intermediates between producer and low-income end consumer. An explanation of that case study, and the methods used to investigate it, now follows.

\section{Researching the Mobile Sector}

\subsection{Case Justification}

We draw here on a qualitative case study that focuses on the integrated processes of innovation and diffusion that have occurred as mobile phone handsets have been adopted by low-income consumers in Kenya. The intention is to use the case as an in-depth analytical tool (Yin, 1994) in order to instantiate the issues proposed in the literature review which may arise in using Sol to understand inclusive innovation. 
This particular case was chosen because it is inclusive in a number of aspects. The system outputs - mobile handsets - have reached very large numbers of low-income consumers. Figures for 2011 indicate 65 mobile subscriptions per 100 inhabitants, a figure which rises to 110 per 100 inhabitants if one excludes the $42 \%$ of the population aged under 15 (CIA, 2012; ITU, 2012). With around half of the population living on less than US\$2 per day - a typical criterion for poverty - this means mobile phones have spread to many millions of poor consumers (Economist, 2011). Research has shown the benefits that mobiles in Kenya are bringing to low-income groups (Jack and Suri, 2010), so inclusivity of both adoption and impact were already demonstrated when this case was selected. In addition, as discussed below, there is inclusivity in some "innofusion" processes since these involve micro-entrepreneurs often drawn from low-income communities.

Information and communication technologies - mobile phones especially - are the basis for a number of examples of innovations that have successfully been rolled out to marginal and poor consumers through processes of adaptive innovation (Prahalad, 2009). They form a case example that is found in all other developing countries, thus enhancing the potential consideration of results in other contexts. But Kenya represents a particularly mature and scaled-up example; such examples offering the opportunity for expanded analysis of key issues that might elsewhere be incipient (Schofield, 2002).

\subsection{Kenya's Mobile Phone Handset Sector}

Like a number of other new goods and services that reach a broad range of consumers in developing countries (London and Hart, 2004; Simanis and Hart, 2009), distribution of phone handsets in Kenya operates via a "dual channel" system, as illustrated in Figure 1.

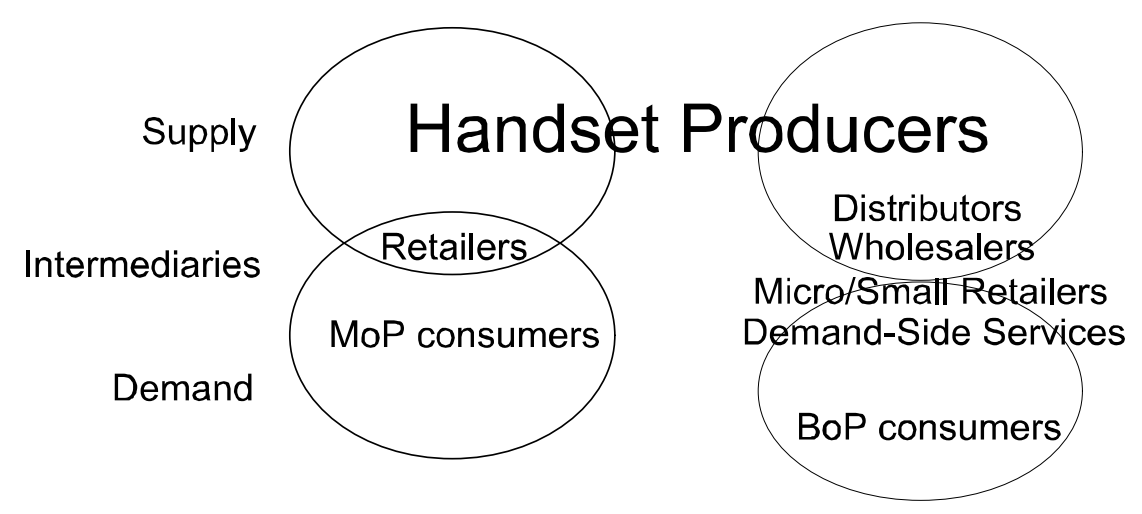

Figure 1: The dual channels of Kenyan mobile handset "innofusion"

More formal retail stores - typically located in retail or residential areas of large towns and cities - tend to focus on middle-of-the-pyramid (MoP) consumers; defined as those earning US\$2-20 per day (Ncube et al., 2011). There was relatively little evidence from fieldwork of innovative activity in relation to this channel, and the chain from supplier to consumer was relatively short. 
Bottom-of-the-pyramid consumers buy through different channels; normally through one of the many informal sellers based in trading areas or marketplaces in marginal locations such as slums, small towns or villages ${ }^{i}$. These micro- - occasionally small - enterprises in turn link to other intermediaries. Their suppliers were mainly wholesalers who buy from a range of, often Chinese, sources, or more formally-appointed distributors. In either case, they may import phones themselves or work with an importer. The handset producers and these suppliers are therefore at some steps removed from their end market with less control over, and a more important role for, the various lower-level intermediaries. Those intermediaries also include microenterprises providing demand-side services, such as phone repairers or sellers of airtime. (For MoP customers, these are roles generally performed by the retailer.)

Estimates from fieldwork suggested that BoP channels account for at least $40 \%$ of all handset sales, with MoP channels accounting for a further $40 \%$ ii, and larger business/government organisation sales the remaining $20 \%$. For some smaller handset brands, up to $90 \%$ were sold via BoP channels, and it is those channels - especially the relation between handset suppliers, micro-enterprise sellers, and low-income consumers - that are the main focus of this study.

\subsection{Research Methods}

Qualitative research methods were used to analyse inclusive innovation in Kenya's mobile handset sector: detailed interviews, observation and document analysis. As summarised in Table 2, interviews were undertaken with a range of actors identified in the innovation system: local representatives of handset producer firms, wholesalers/distributors, mobile handset retailers, other demand-side micro-entrepreneurs, and policy makers.

Interviews were semi-structured, undertaken during 2010 and 2011, and intended to provide clear understanding of the contribution of actors to innovation, and of their view on the learning processes, institutions and relations within the system of innovation. In order to understand practices more clearly, interviews with wholesalers, sellers and other micro-entrepreneurs were undertaken within their work setting. This provided additional observational data - e.g. interactions with consumers or other innovation system actors which was incorporated into the data record. Discussions with handset producers and policy makers were supplemented by analysis of available reports, policies, etc, and the latter also involved participation in four open forum discussions of telecommunications and ICT policy in Kenya attended by policy makers, advisors and lobbying groups.

\begin{tabular}{|l|l|l|}
\hline Innovation System Actor & Methods & $\begin{array}{l}\text { Number of } \\
\text { Interviews }\end{array}$ \\
\hline Policy Makers & $\begin{array}{l}\text { Interviews, Policy } \\
\text { Documents, Policy } \\
\text { Discussions }\end{array}$ & 12 \\
\hline Handset Producers & $\begin{array}{l}\text { Interviews, Sectoral } \\
\text { Studies }\end{array}$ & 7 (in 6 firms) \\
\hline Wholesalers and Distributors & Interviews, Observation & 20 \\
\hline
\end{tabular}




\begin{tabular}{|l|l|l|}
\hline Mobile Handset Sellers & Interviews, Observation & 27 \\
\hline $\begin{array}{l}\text { Other Demand-Side Actors } \\
\text { (repairers, mobile airtime, sim and } \\
\text { accessory sellers) }\end{array}$ & Interviews, Observation & 15 \\
\hline Total & & 81 \\
\hline
\end{tabular}

Table 2: Kenyan mobile handset case study research methods

\section{Inclusive Innovation Domains}

Analysis of field data on the value chain from handset producers to low-income consumers identified four main domains of relevance to inclusive innovation. These are detailed below, and relate to four things necessary for diffusion of a new technology to poor consumers: a product that is appropriate and saleable to such consumers; actual sales and support of that product; survival of the enterprises that sell and support; and a supportive socio-economic context.

\subsection{Product Innovation}

Outputs of innovation systems will become more inclusive as products are specifically (re)designed to take account of the needs and context of marginalised groups. Different actors approached this in different ways in the Kenya case.

Managers in multinational handset producers were increasingly interested in bottom-of-the-pyramid consumers, and reported their firms had commissioned user research and survey activities among low-income groups. This had led to some adaptations. There had been improvements in antenna range and battery life to cope with the lower coverage of mobile and electricity networks experienced by rural users. Lower-cost phone models had been designed with just a cut-down set of features or with simpler interfaces for lower-literacy usage. These phones, though, were often universal - basic models intended to serve BoP markets across several continents, and not innovated to address individual market needs. Thus mobile retailers embedded in poor communities in Kenya felt the multinational manufacturers were slow and limited in responding to local user needs.

New producers have stepped in to fill this "innovation gap"; particularly Chinese mobile handset firms which have had a more dedicated focus on lower-income markets. Their market research has been less extensive and less formal than that of the multinationals. But it has been more tied in to suggestions from intermediaries in the Kenyan "BoP channel", and more quickly and more often incorporated into later phone models. Examples include dual sim card phones (allowing users to choose the lower-cost network to phone particular contacts), translation of the phone interface into Swahili, and addition of a single-buttonenabled new interface for the popular M-Pesa mobile money service. The result has been capture of significant market share by the Chinese firms: estimated by respondents at between $20-40 \%$ of all phones, and much higher among low-income groups. This is all the more notable given the tiny marketing budgets these firms have in comparison to the multinational brands. 
The literature records some examples of direct product innovation by intermediaries being a significant force in the wider mobile sector in some developing countries (Goodman and Walia, 2006; Hughes and Lonie, 2007). However, such activities were not found in this case, in part because the nature of handset technology - its complexity and lack of flexibility - locks out the possibility of post-manufacture innovation. Phone repairers might undertake minor adaptations, e.g. fitting a non-standard battery to a phone. But activities were otherwise limited to "configurational" actions; that is, those which set up the technology for use in a particular way (Fleck, 1994). For example, sellers were seen setting up the radio functionality of phones for purchasers, or setting phones up for mobile money usage. They were therefore building acceptance and use of the products by aligning them with local needs, sometimes in ways not originally envisaged by the manufacturers.

\subsection{Innovation and Retail}

A new good or service may be appropriate to low-income consumers, but it will not have an inclusive impact unless it diffuses into that market and is adopted. A first step will be awareness of the product, and there had been various marketing innovations in order to reach BoP markets. The manager of a new entrant handset firm, for example, described setting up billboard advertisements at key points in low-income communities, developing locallanguage radio and TV advertisements, and sending individual marketing agents into those communities with posters, stickers and caps to distribute to small shopkeepers and others.

Low-income consumers typically buy from local outlets, so the majority of handset sellers are located within poor communities, working from kiosks, shacks and market stalls. To reach even further into some of the least-secure and most-excluded locations, one entrepreneur was using a gazebo-like structure to create a mobile "shop" that could be quickly set up by a local retailer to sell phones during the day, and then dismantled and removed at night.

Having such locally-embedded micro-enterprises - an eco-system of mobile sellers, mobile repairers, accessory sellers, airtime sellers and hawkers, payphone operators and mobile money service agents - was an essential part of diffusing handsets into BoP markets since the entrepreneurs rework this external technology into the realities of their specific context; something they often referred as "customer service". For instance, one handset seller was observed explaining and demonstrating a phone to a sceptical customer. Rather than simply showing the features, she embarked on a long personal story about how she bought her elderly rural relations a mobile phone in order to stay in touch during family crises, and how she was able to help them financially through mobile money transfer, demonstrating the exact activities she undertook. Another explained to low-income customers how to use "beeping" - calling a contact at no cost by just registering a missed call - in order to get a call back when out of airtime. Many other examples were seen of this "thick interaction": being told stories about use of technology, demonstrating and testing out products, and engaging in price negotiations 
which might include provision of short-term credit on phone purchases to trusted customers. In some cases, sellers in the most marginal communities were more like local "fixers": consumers, who lack confidence and knowledge, would come to them not just for sales but also to have features demonstrated, or to get phones taken away for repair.

Beyond marketing, such activity locates abstract innovations within actual needs and norms and usage, and the ongoing face-to-face interaction between intermediaries and users is crucial in this process. These embedded actors and their activities are central to the diffusion of new technologies into lowincome markets, something recognised by the producers, one of whom stated:

"Distribution is [our] biggest competitive advantage, how we are able to distribute phones through independent distributors into local retailers. Other firms often have to piggyback on operators which gives them less ability to sell low end phones, particularly outside of the big cities".

\subsection{Innovation and Enterprise}

The innovations and "innofusion" activities described so far have been largely demand-driven, but others were driven more by other aspects of context. These include the activities that enterprises embedded in poor communities undertake in order to survive and trade. Constant diversification has been one necessity because of the context of competition and technical change. Any niche market rents are rapidly eroded due to low entry barriers, rapid imitation by other entrepreneurs, and obsolescence of key technologies. Those who survived were those who had the most effective links downwards into their consumer markets, and upwards into the ever-evolving world of technology suppliers. They were able to match the two by identifying a range of innovative products and then selecting those technologies which would best find market demand among low-income consumers.

They, for example, picked up quickly and acted on trends such as selling the locally-adapted phones described above, and moving into new services such as mobile money and mobile internet access. Looking backwards, similar patterns were discernible, with dynamic enterprises having had histories in one or more of: video hire, music cassette sales, photo shops, TV/video/computer repair, and shared public phone use. These patterns speak to both the opportunities for learning and change present in a dynamic innovation system, but also to the uncertainties of growth and fragility of survival experienced by less-affluent actors in such systems.

Alongside these broader forces of competition and technical change, innovative enterprise practices were also shaped by more micro-level variables within the local environment. A number of mobile sellers had, for example, adopted a "one phone out, one phone in" approach to restocking; often visiting wholesalers several times a day. This is inconvenient and it eliminates the potential for lower-cost bulk purchases. But it reduced the amount of cash carried and required to make wholesaler purchases, and it made it easier to monitor what was going on in the micro-enterprise when - as often - it was left in the charge of an assistant that the entrepreneur did not completely trust. 
Other enterprise-related innovations arise due to the nature of local police and council enforcement, with many sellers having experienced problems: demands for additional licences, or loss of goods deemed to be counterfeit or illegal. These actions were seen as ad hoc and often associated with requests for bribes in order to ignore the alleged infringements. To reduce losses and harassment or even to stay trading, one innovative response from a number of micro-entrepreneurs had been symbolic compliance: the overt use of legitimating objects, symbols and technologies that were a misdirection as to the true nature of the enterprise. These might be display of common handsets, use of advertising posters or logos or colours associated with mobile operators and services, or prominent display of technologies like photocopiers or standard green payphones that were in practice superseded and largelyunused. It also included displays of local trading licences (even when well outof-date), use of business cards and official-looking name badges, or adopting the style of jacket common among informal sector workers.

In part, these things were legitimation devices with local consumers, but they were also aimed at representatives of authority. An illustration was a kiosk run by Joseph and Badru, two mobile phone repairers who had suffered continuous problems in the past, as Joseph outlined:

"before, we had some visits from askaris [local police] who said that we were unlocking Safaricom phones and that unlocking Safaricom phones was illegal. They came and took away our tools [referring to repair equipment], this is why we work in the back".

"Work in the back" refers to their symbolic compliance actions, which had been to appear, externally, to be a mobile phone sales outlet, with handsets and sales posters prominently displayed. In practice, they only sold about one phone per month, and their living was made from phone repair; work hidden at the back of the kiosk, and not visible to passers-by. Significant capital particularly for this type of financially-marginal enterprise - was tied up in the displayed handsets. But this was deemed a worthwhile investment for the protection it offered.

In sum, these enterprise-related innovative practices are driven by the local context, as were the product- and retail-related innovations. However, they are somewhat orthogonal to the other innovations. They do not particularly serve to increase the diffusion of the new technology into low-income markets. Indeed, they arguably divert intermediaries' time and energies from technologyadaptive innovations and diffusion-maximisation activities. But what they do ensure is the continuing survival of these actors who are so essential to inclusive innovation.

\subsection{Innovation and the Wider Context}

It would be wrong to see the wider context just as problematic for innovation intermediaries. Some aspects - the role of handset wholesalers, and the role of national policy - have been more supportive of their "innofusion" activities, and must therefore be recognised as an important part of the innovation system. 
Handset wholesalers are themselves intermediaries, sitting between the producers and the micro-enterprise retailers. They have often built relationships with both over an extended period, and perform valuable roles for both. A number of the micro-retailers recounted early points in their histories when wholesalers extended short-term credit or pay-and-return conditions which had allowed them to survive in business. Wholesalers absorbed exchange rate fluctuations - buying from branded producers in US dollars, selling to retailers in Kenyan shillings - that could have been financially damaging to the latter.

They also supported the equivalent of reverse innovation flows. In the case of the Chinese generic handset producers (though less visible with the branded multinationals), some wholesalers aggregated ideas and suggestions for product adaptations from their retailers, and passed them on to the producers, with evidence of incremental product innovations later emerging. They were therefore the conduit by which the needs of poor consumers helped drive product innovation. While not particularly innovative themselves, the wholesalers should thus be seen as a crucial part of the innovation system. They help embedded retailers to survive, and support reverse flows of innovative ideas from the demand side.

Second, certain national policies can be seen as indirectly supporting the innovation system and its key actors. Although prompting ongoing diversification, competition policy has allowed dynamic entrepreneurs to stay in business even as some product markets become saturated or obsolescent. The constant flow of new uses of mobile phones - from basic airtime, phone sales, and repairs through mobile money to more recent mobile web and mobile finance applications - has enabled innovation intermediaries to learn and survive. Equally, competition has pushed large producers and operators to seek out lower-income consumers, forcing at least some focus on adaptation towards those users.

Policy has also acted to some degree to reduce the instabilities and insecurities of those intermediaries embedded in low-income communities; helping them be less pre-occupied with risk-reduction innovations, and invest more in demandfocused innovations. One example is the development of single business licences (Mitullah, 2003). These allowed many of the mobile sellers working in Nairobi's low-income areas to purchase a single yearly licence from the local council. They could then work in kiosks or other informal locations with a much-reduced risk of having to pay a bribe for licence contravention, and having to spend less of their time thinking of innovative ways to avoid the attention of local enforcement authorities. iii

Finally, liberalisation of banking policy in Kenya has brought greater financial security and stability to the country's micro- and small enterprises (FSD Kenya, 2009). During interviews, all mobile retailers and nearly all the other innovation system actors were found to have some sort of bank account, which provided safer control of finances. Even with their informal nature, some mobile sellers were also able to get loans from banks to start or grow their businesses; helping consolidate their role in the innovation system. 


\section{Discussion: Conceptualising Inclusive Innovation}

The findings above explain what was necessary in order to bring an innovative product to use by millions of low-income consumers i.e. to create inclusive innovation adoption and impact, through a partly-inclusive innovation process (better-termed an "inclusive innofusion" process). We now turn to discuss those findings in light of the literature review conducted above. Specifically, we will check the contents of each systems of innovation component, as summarised in Table 1, and analyse how those relate to the findings of the case study.

\subsection{Innovation}

The findings confirm the earlier proposition that the nature of inclusive innovation is rather different from that traditionally conceived by systems of innovation frameworks. All the innovations identified have been relatively minor, many have been quite specific to the localised needs of low-income customers, and many relate more to the social systems of selling and supporting the new technology than to the technology itself.

The notion of innofusion seems to work well: an intertwining of processes of innovation and diffusion in which "user needs and requirements are discovered and incorporated in the course of the struggle to get the technology to work in useful ways" (Fleck, 1988:3). The key phrase here for inclusive innovation is "work in useful ways". Often for bottom-of-the-pyramid markets, poor knowledge of needs or lack of adaptation renders new technologies less useful to recipients (Heeks, 2002). What is needed is an interlinking of the supply side (traditionally the domain of innovation) and the demand side (traditionally the domain of diffusion).

The invented technology of the standard mobile phone was of limited utility to low-income consumers. To improve that utility, a whole set of minor innovations has been required. Some of these were located within the supplyside producers but even some of those were reliant on flows of knowledge from the "innofusion intermediaries"; particularly the demand-linked microenterprises embedded in poor communities who diffuse the technology but also themselves innovate in various minor ways:

- Appropriations (Cheneau-Loquay, 2010): minor changes in the products, such as modifications undertaken by phone repairers.

- Configurations (Fleck, 1994): setting up the technology in particular ways of specific utility to poor consumers, such as radio or mobile web or mobile money functionality.

- Use variations (Edgerton, 1999): variations from the anticipated uses of the technology, such as guidance on beeping.

- Domestication (Stewart and Hyysalo, 2008): changes in not just the practical but also the "symbolic and cognitive dimensions in the selection, deployment and adaptation of new technologies" (ibid.:317), such as helping local users understand the connection between the technology and their own needs, priorities and norms. 
It is certainly necessary to move beyond the supply-orientation of earliest ideas on innovation, in relation to the main locus of innovation, but also in terms of the drivers to innovation. A little of the activity charted - e.g. diversification was related to the supply side, but innovation was mainly demand-driven like those listed just above, or driven by other aspects of context, such as the riskreduction innovations reacting to the local institutional environment. Some of the innovations remained rooted in their locale; the basis for a growing heterogeneity of practice. But - via a reverse innovation flow not seen in conventional models - others were taken up by higher-level intermediaries and actors, and scaled across the innovation system more broadly, demonstrating a "wider applicability beyond the specific contingencies which gave them birth" (Fleck, 1993:172).

\subsection{Actors}

Conventional systems of innovation frameworks have been broadened to incorporate demand-side actors and of intermediaries, but the findings have exposed the exact nature of these actors in systems of inclusive innovation, at least for this case. They have identified key intermediary roles which have been essential to enable adoption and use of new technology by low-income consumers.

Where the "distance" (more in a cognitive and institutional than geographic sense) between supply and demand is limited - as it was for middle-of-thepyramid consumers - then a relatively simple and relatively un-innovative set of intermediaries arise. Where, though, bottom-of-the-pyramid markets are being served, a much richer network of intermediaries must be created; a network that must produce a whole set of minor adaptive innovations in order to ensure inclusivity: technology adoption and use and impact within those markets.

In general, these are not innovation intermediaries as R\&D brokers. The closest to that is the role of the wholesalers who act as a bridge between demand and supply; connecting those who can redesign the technology - the producers - with those who understand how that technology needs to be used in practice, and thereby enabling innovation.

The wholesalers provide some stability and security for the main group of intermediaries identified here: the micro-enterprises that sell and support mobiles. They are intermediaries since they stand in the value chain between producer and consumer; and they are also innovative in a myriad of small ways that ensure diffusion and use of the technology. But this is a different kind of innovation intermediary to that seen in the Sol literature, and best understood through the term "innofusion intermediary".

As a group, they are neither completely formal yet nor are they completely informal since they share features of both given the various criteria applied to these terms (Gërxhani, 2004). What they do is not illegal and many have government business licences and formal recording systems, yet they stand outside many labour, financial and other regulations; they are tiny in size; and 
they mix a business and social orientation. As such, they may best be described as "less formal" or "semi-formal" rather than informal.

\subsection{Learning}

It has certainly been possible to see examples of Lundvall's doing-usinginteracting categorisation of types of learning as part of this inclusive innovation case. But the emphasis has been slightly different to that in most Sol cases, given the focus on the diffusion and domestication of the technology. The innofusion intermediaries have therefore learned mainly about the "doing" of retail sales and support processes and about the "using" of the technology

The core has been an interactional learning that was at least three-way. Supply-side interaction with wholesalers has brought knowledge about, for example, retail practices and new products and services for potential sale. Demand-side interaction with customers has been the main source for innovation, helping them understand what technology adaptations and configurations, and what "retail configurations" are required for diffusion and use. Other context interactions have triggered the adaptations necessary to survive as an enterprise serving low-income communities. (Though not really discussed here, we could also add lateral interactional learning: the imitation of business practices by micro-enterprise peers.) In all, then, there is a very rich set of interactional bases which orientate the learning of these intermediaries.

The case supports the critique of Sol ideas on learning; that they may assume coherence and systemic instrumentality. The learning of micro-enterprise intermediaries is not just driven by interactions within the system, and is not just focused on systemic profit maximisation. Instead, wider contextual influences also drive learning, and these actors are utility-maximising in a much more locally-focused sense. Part of their learning and innovation related to survival in an uncertain and volatile environment. This does have a systemic functionality since technology could not diffuse effectively if these actors could not exist and survive, but it does represent an additional set of factors and learning processes to supplement Sol models when they seek to encompass inclusive innovation.

\subsection{Relations}

As outlined above, the systems of innovation literature saw differences in outcome between systems with tight relations between actors (i.e. a few close reciprocal relations based on continuous interactions), and those with much looser relations. The former were seen to produce greater system coherence, and greater efficiency in innovation performance. This was recognised also in inclusive innovation literature but so, too, was the value of looser, more flexible relations to allow differentiated innovation to meet diverse local needs.

In this case of inclusive innovation, the relations between innovation system actors have in some ways been relatively "arms' length" market relationships, though the economic side of the relation increasingly sits alongside a social aspect as one moves from the supply to the demand side. Certainly, the producers sit at some remove from the sites of sales and consumption, and have not sought to exert control. With the same being true of wholesalers, this 
has allowed the flexibility for embedded micro-enterprises to follow the path for technology diffusion that they feel is most locally-appropriate. As predicted, though, this is not without its downsides. The branded manufacturers are leastwell connected to low-income markets, and have gained only limited understanding of those markets, with knock-on constraints on their innovation. The spread of technological and retail best practice among the innofusion intermediaries via reverse or lateral innovation flows, is sporadic.

The nature of innovation system relations may therefore, at best, be said to be effective for inclusive innovation but not particularly efficient. So the Sol assumptions about relations are partly vindicated, with further work required to identify the optimum relations for diffusion of new goods and services to lowincome groups. Even if that optimum could be identified, however, a further question arises about the potential to change actor relations. As noted, these are not simply market relations and, as discussed next, they remain embedded in an institutional context that constrains change.

\subsection{Institutions}

Sol frameworks have tended to focus on formal institutions, particularly those which deal directly with innovation. Respondents did not identify state institutions of this type playing a role in this case, but there was instead indirect support for inclusive innovation. Competition policy induced handset producers to take note of low-income markets, enhancing the ability of other actors to address those markets and to innovate. Basic business rules and banking reforms and systems reduced instabilities, gave embedded local actors more security and predictability, and lessened the extent to which they needed to engage in uncertainty-reduction innovations.

But the bigger institutional story was of a rich and highly complex institutional terrain including not just rules but also informal institutions; innofusion intermediaries' own practices and cognitive understandings; local markets and their customs; and the rules, legitimacy and practices encapsulated within innovations. In particular, there was a leitmotif of informal institutional forces. These helped, for example, shape the emergence of adaptive innovations like the local "fixer" role and the use of short-term credit but also the insecurity and lack of trust that shaped restocking behaviour. Local informal institutional norms also subverted formal rules, and pushed entrepreneurs to innovate in rather inefficient ways such as adoption of symbolic compliance in order to reduce their uncertainties.

So the ideas from the literature review are supported: formal state institutions do play a role in inclusive innovation but much less directly; those formal institutions are also less forceful within low-income markets, partly because of implementation gaps, and partly due to the rich informal institutional system that shapes behaviour in and around these markets. 


\section{Summary and Conclusions}

Inclusive innovation produces new goods and services for those on lowest incomes but has so far been rather under-researched and underconceptualised. As suggested by the literature review and as demonstrated by the case study, it is entirely appropriate to use a systems of innovation framework to understand inclusive innovation: there is a system of actors who inter-relate, learn and innovate within an institutional environment. The framework has previously been broadened to recognise some of the aspects that are typical of inclusive innovation, and we have here systematically extended that process: showing that inclusive innovation systems can also be encompassed.

The literature review indicated that the component placeholders of the innovation system would likely be the same when analysing inclusive innovation, but that the contents of each component would be rather different. Most of those differences were validated by the case study, but some adjustments and augmentations have also emerged. These are included in Table 3 (alterations and additions shown in italics), which presents our overall summary of the content differences between conception of a conventional system of innovation and that required for an inclusive system of innovation.

\begin{tabular}{|c|c|c|}
\hline & $\begin{array}{l}\text { Conventional Systems of } \\
\text { Innovation }\end{array}$ & Inclusive Systems of Innovation \\
\hline $\begin{array}{l}\text { Overall } \\
\text { Scope }\end{array}$ & $\begin{array}{l}\text { Development as economic growth } \\
\text { - Macro-level analysis }\end{array}$ & $\begin{array}{l}\text { Development as socio-economic } \\
\text { inclusion } \\
\text { - Micro-level analysis of livelihoods }\end{array}$ \\
\hline \multicolumn{3}{|c|}{ Structure and Process Components } \\
\hline Innovation & $\begin{array}{l}\text { Located innovation pre, durante } \\
\text { and post-production } \\
\text { - Growth-oriented innovation } \\
\text { - Supply-driven innovation } \\
\text { - Technical innovation }\end{array}$ & $\begin{array}{l}\text { Incremental innovation with a focus on } \\
\text { diffusion processes } \\
\text { - Local needs-oriented innovation as } \\
\text { appropriation, configuration, use } \\
\text { variation, domestication } \\
\text { - Demand-driven and context-driven } \\
\text { innovation } \\
\text { - Non-technical innovation with focus on } \\
\text { social systems of sales and support } \\
\text { - Reverse innovation }\end{array}$ \\
\hline Actors & $\begin{array}{l}\text { Main focus on: } \\
\text { - Higher-income } \\
\text { markets/consumers } \\
\text { - Formal supply-side organisations } \\
\text { in industrial sectors } \\
\text { - Innovation intermediaries as R\&D } \\
\text { brokers }\end{array}$ & $\begin{array}{l}\text { Main focus on: } \\
\text { - Low-income consumers } \\
\text { - Non-traditional, less formal, demand- } \\
\text { side innovators } \\
\text { - Chain of innofusion intermediaries } \\
\text { linking "distant" supply and demand }\end{array}$ \\
\hline Learning & $\begin{array}{l}\text { Learning by doing plus using and } \\
\text { interacting: } \\
\text { - Learning about production and } \\
\text { implementation } \\
\text { - Learning about technology } \\
\text { - Coherence and profit- } \\
\text { maximisation as guides }\end{array}$ & $\begin{array}{l}\text { Contextualised (supply, demand, other) } \\
\text { learning by interacting and using and } \\
\text { doing } \\
\text { - Learning about diffusion (sales and } \\
\text { support) and use } \\
\text { - Learning about wider social processes } \\
\text { including non-instrumental processes } \\
\text { - Survival and utility-maximisation as } \\
\text { guides }\end{array}$ \\
\hline Relations & Formal, close relations preference & $\begin{array}{l}\text { Necessity (but also limitations) of } \\
\text { informal, loose but socialised relations }\end{array}$ \\
\hline
\end{tabular}




\begin{tabular}{|l|l|l|}
\hline Institutions & Formalised, relatively-static, direct- & $\begin{array}{l}\text { Complex institutional terrain of informal } \\
\text { and formal } \\
\text { impact overarching institutions } \\
\end{array}$ \\
& $\begin{array}{l}\text { - Indirect impact of core, formal } \\
\text { institutional forces } \\
\text { - Importance (including potential negative } \\
\text { impact) of informal institutions at local } \\
\text { level }\end{array}$ \\
\hline
\end{tabular}

Table 3: Modifying systems of innovation thinking to encompass inclusive innovation

Conventional Sol models afford a somewhat "taken for granted" status to diffusion and use of new technologies, seeing these activities as relatively straightforward and stable. Micro-level analysis showed this not to be the case for inclusive innovation. Extensive, complex, volatile, embedded networks of innovation system actors were required to ensure low-income consumers can access and use new goods and services. These must be seen as part of the innovation system, not least because successful diffusion itself demands technical, social and socio-technical innovations; an interknitting that justifies understanding the processes as "innofusion".

Inclusive innofusion was seen to require four domains of the innovation system to be effective. The system had: to produce something that could be sold and used; to enable actual sales and ongoing support of the product; and to enable survival of the core intermediaries responsible for sales and support. It also needed a wider context that was, on balance, more rather than less supportive of innofusion. Our study could have focused mainly on producers or suppliers or consumers within the system. However, the key innofusion actors - not generally recognised or a part of typical systems of innovation cases - were the demand-side micro-enterprises embedded in poor communities who had some role to play in all four domains.

The relations, learning and innovations of these actors bring specific features to this type of inclusive innovation system. Their supply, demand and other contextual environment is different from that of large firm producers, and so their innovations are not always aligned with the profit-maximisation goals of the producers; yet they were seen to be necessary in order for the producers' innovations to reach low-income markets. At first sight they might appear peripheral to the innovation system, with their often-marginal livelihoods, their limited and typically process- not technology-oriented innovations, and the influence of informal institutions upon them. Yet they underpin the performance of the whole innovation system, and require us to move beyond conventional Sol conceptions of innovation components and processes.

Adjusting the innovation systems model to cater for inclusive innovation also necessitates a changed perspective on lead firm strategies and on innovation policy. For the former, we have identified the potential mismatch between lead firm profit-maximising goals, and the utility maximisation of the inclusive intermediaries. Effective strategy must therefore understand these mismatches and their causes, looking for ways to support the low-level actors working in unstable environments. Lead producer firms can also find ways to link more 
effectively with the micro-enterprises to learn from, and magnify the effects of, bottom-up innovations arising on the demand side. This may require lead firm strategy to move away from conventional approaches and relations, but this will be necessary if the inclusive innovation system is to be as effective as possible.

Inclusive innovation policy is also likely to be rather different from customary innovation policy. Notably, this highly successful innovation has barely seemed affected by innovation policy, with only indirect impacts seen from policies in other areas - competition, business, banking - and an even more indirect effect arising from the limited on-the-ground implementation of some measures. Strengthening of these types of relatively generic business policies is likely to be useful. However, policy making must begin by understanding not just largescale formal actors and institutional forces, but also the micro-enterprises and the more informal institutions that characterise the low-income markets and contexts in which they operate. Light-touch, adaptive policy making that identifies inclusive innovation system weaknesses is likely to be the order of the day.

The overall contention here seems generalisable. The broad applicability of systems of innovation thinking to inclusive innovation but the need for content modification were derived from a review of literature and supported by the case analysis. Likewise, our approach to understanding systems of innovation in terms of the five components: innovation, actors, learning, relations, and institutions. The italicised modifications shown in Table 3 are specifically derived from just a single country and sector - albeit one that will be of central importance to inclusive development as the $21^{\text {st }}$ century progresses. It does have particular features; for example the relatively-limited malleability of the technology compared to those present in some other innovation systems.

Thus, while we can be confident in the general applicability of the overall findings; some of the specifics will benefit from further application. This modified framework can now be applied as an analytical lens for understanding other cases of inclusive innovation; perhaps cases involving less novel technologies and where indigenous knowledge and competencies are already well-established within poor communities. Such research is advised to follow the methodological adjustment that has sat alongside the conceptual one: focusing less on the macro-analysis of structure, focusing more on micro-level analysis of innovation processes and livelihoods.

\section{References}

Altenburg, T. (2009) Building Inclusive Innovation Systems in Developing Countries: Challenges for IS Research. In: B.A. Lundvall, K.J. Joseph, and C. Chaminade (eds) Handbook on Innovation Systems and Developing Countries: Building Domestic Capabilities in a Global Context. Cheltenham, UK: Edward Elgar, pp. 33-57.

Bell, M. and Pavitt, K. (1993) Technological accumulation and industrial growth: contrasts between developed and developing countries. Industrial and Corporate Change 2(1): 157210. 
Brinkerhoff, D.W. and Goldsmith, A.A. (2005) Institutional Dualism and International Development. Administration \& Society 37(2): 199-224.

Chaminade, C., Lundvall, B.A., Vang, J. and Joseph, K.J. (2009) Designing Innovation Policies for Development. In: B.A. Lundvall, K.J. Joseph, and C. Chaminade (eds) Handbook on Innovation Systems and Developing Countries: Building Domestic Capabilities in a Global Context. Cheltenham, UK: Edward Elgar, pp. 360-378.

Cheneau-Loquay, A. (2010) Innovative Ways of Appropriating Mobile Telephony in Africa. Geneva: ITU.

CIA (2012) The World Factbook: Kenya. Washington, DC: Central Intelligence Agency.

Codagnone, C. (ed.) (2009) Vienna Study on Inclusive Innovation for Growth and Cohesion. Brussels: European Commission.

Cozzens, S. and Sutz, J. (2012) Innovation in Informal Settings: A Research Agenda. Ottawa: IDRC.

DeBresson, C. and Amesse, F. (1991) Networks of innovators: a review and introduction to the issue. Research Policy 20(5): 363-379.

Economist (2011) Pleased to be bourgeois, 12 May

Edgerton, D. (1999) From innovation to use: ten eclectic theses on the historiography of technology. History and Technology 16(2): 111-136.

Edquist, C. (1997) Systems of Innovation Technologies, Institutions and Organisations. London: Pinter.

Edquist, C. (2001) The Systems of Innovation Approach and Innovation Policy. Paper presented at DRUID Conference; 12 June, Aalborg, Denmark.

Edquist, C. (2005) Systems of Innovation: Perspectives and Challenges. In: J. Fagerberg, D.C. Mowery, and R.R. Nelson (eds) The Oxford Handbook of Innovation. Oxford: Oxford University Press, pp. 181-208.

Edquist, C. and Hommen, L. (1999) Systems of innovation: theory and policy for the demand side. Technology in Society 21(1): 63-79.

Edquist, C. and Johnson, B.H. (1995) Institutions and Organisations in Systems of Innovation. In: C. Edquist (ed) Systems of Innovation Technologies, Institutions and Organisation. London: Pinter, pp. 41-64.

Fleck, J. (1988) Innofusion or Diffusation, PICT Working Paper. Edinburgh: University of Edinburgh.

Fleck, J. (1993) Innofusion: Feedback in the Innovation Process. In: F.A. Stowell, D. West and J.G. Howell (eds) Systems Science. New York, NY: Plenum Press, pp. 169-174.

Fleck, J. (1994) Learning by trying: the implementation of configurational technology. Research Policy 23(6): 637-652.

Foster, C. and Heeks, R. (2010) Researching ICT micro-enterprise in developing countries. Electronic Journal of Information Systems in Developing Countries 43(7): 1-20. 
Freeman, C. (1995) The "national system of innovation" in historical perspective.

Cambridge Journal of Economics 19(1): 5-24.

FSD Kenya (2009) FinAccess National Survey 2009: Dynamics of Kenya's Changing Financial Landscape. Nairobi: Financial Sector Deepening Kenya.

Fu, X., Pietrobelli, C. and Soete, L. (2011) The Role of Foreign Technology and Indigenous Innovation in the Emerging Economies: Technological Change and Catchingup. World Development 39(7): 1204-1212.

Gërxhani, K. (2004) The informal sector in developed and less developed countries. Public Choice 120: 267-300.

Goodman, J. and Walia, V. (2006) A Sense of Balance: A Socio-Economic Analysis of Airtime Transfer Service in Egypt. London: Forum for the Future.

GSMA (2011) Mobile Telephony and Taxation in Kenya 2011. London: GSM Association.

Heeks, R. (2002) Information systems and developing countries: failure, success, and local improvisations. The Information Society 18(2): 101-112.

Horton, D. (2008) Facilitating Pro-Poor Market Chain Innovation. Lima: Papa Andina.

Howells, J. (2006) Intermediation and the role of intermediaries in innovation. Research Policy 35(5): 715-728.

Hughes, N. and Lonie, S. (2007) M-PESA: mobile money for the "unbanked" turning cellphones into 24-hour tellers in Kenya. Innovations 2(1-2): 63-81.

IDRC (2011) Innovation for Inclusive Development: Program Prospectus for 2011-2016. Ottawa: IDRC.

ITU (2012) ICT Statistics Database. Geneva: International Telecommunication Union.

Jack, W. and Suri, T. (2010) The Economics of M-Pesa: An Update. Boston, MA: MIT Sloan.

Johnson, B.H. (1992) Institutional Learning. In: B.A. Lundvall (ed) National Systems of Innovation: Towards a Theory of Innovation and Interactive Learning. London: Pinter, pp. 23-45.

Joseph, K.J. (2012) Spaces of Exclusion in the Institutional Architecture for Innovation. Paper presented at $10^{\text {th }}$ Globelics International Conference, 9-11 November, Hangzhou.

Joseph, K.J., Chaminade, C., Dutrenit, G., Sutz, J., Muchie, M., Cozzens, S. and Turpin, T. (2011) Editorial. Innovation and Development 1(1): 1-3.

Kaplinsky, R. (2011) Schumacher meets Schumpeter: appropriate technology below the radar. Research Policy 40(2): 193-203.

Kaplinsky, R., Chataway, J., Clark, N., Hanlin, R., Kale, D., Muraguri, L., Papaionnou, T., Robbins, P. and Wamae, W. (2009) Below the radar: what does innovation in emerging economies have to offer other low-income economies? International Journal of Technology Management and Sustainable Development 8(3): 177-197.

King, K. (1996) Jua Kali Kenya: Change \& Development in an Informal Economy, 1970-95. Athens, $\mathrm{OH}$ : Ohio University Press. 
Kraemer-Mbula, E. and Wamae, W. (2010a) Innovation and the Development Agenda. Paris: OECD/IDRC.

Kraemer-Mbula, E. and Wamae, W. (2010b) Adapting the Innovation Systems Framework to Sub-Saharan Africa. In: E. Kraemer-Mbula and W. Wamae (eds) Innovation and the Development Agenda. Paris: OECD/IDRC, pp. 65-86.

London, T. and Hart, S.L. (2004) Reinventing strategies for emerging markets: beyond the transnational model. Journal of International Business Studies 35(5): 350-370.

Lundvall, B.A. (1992a) National Systems of Innovation: Toward a Theory of Innovation and Interactive Learning. London: Pinter.

Lundvall, B.A. (1992b) Introduction. In: B. A. Lundvall ed. National Systems of Innovation: Towards a Theory of Innovation and Interactive Learning. London: Pinter, pp. 1-22.

Lundvall, B.A. and Intarakumnerd, P. (2006) Asia's Innovation Systems in Transition. Cheltenham, UK: Edward Elgar.

Lundvall, B.A., Joseph, K., Chaminade, C. and Vang, J. (eds) (2009a) Handbook on Innovation Systems and Developing Countries: Building Domestic Capabilities in a Global Context. Cheltenham, UK: Edward Elgar.

Lundvall, B.A., Vang, J., Joseph, K., and Chaminade, C. (2009b) Innovation System Research and Developing Countries. In: B.A. Lundvall, K. Joseph, C. Chaminade and J. Vang (eds) Handbook on Innovation Systems and Developing Countries: Building Domestic Capabilities in a Global Context. Cheltenham, UK: Edward Elgar, pp. 1-33.

Mackintosh, M., Chataway, J. and Wuyts, M. (2007) Promoting innovation, productivity and industrial growth and reducing poverty: bridging the policy gap, European Journal of Development Research19(1): 1-12.

Mathews, J.A. and Cho, T. (2000) Tiger Technology: The Creation of a Semiconductor Industry in East Asia. Cambridge, UK: Cambridge University Press.

Matin, I., Hulme, D. and Rutherford, S. (2002) Finance for the poor: from microcredit to microfinancial services. Journal of International Development 14: 273-294.

Mitullah, W. (2003) Street Trade in Kenya the Contribution of Research in Policy Dialogue and Response. Paper presented at Urban Research Symposium on Urban Development for Economic Growth and Poverty Reduction; 15-17 December, Washington, DC.

Müller, J. (2010) Befit for Change. Paper presented at FAU Conference; 17-19 March, Djursland, Denmark.

Mytelka, L.K. (2000) Local systems of innovation in a globalized world economy. Industry and Innovation 7(1): 15-32.

Ncube, M., Lufumba, C.L. and Kayizzi-Mugerwa, S. (2011) The Middle of the Pyramid. Abidjan: African Development Bank.

Nichter, S. and Goldmark, L. (2009) Small firm growth in developing countries. World Development 37(9): 1453-1464.

North, D.C. (2009) Institutions, Institutional Change and Economic Performance.

Cambridge: Cambridge University Press. 
Nzepa, O., Keutchankeu, R. and Esse, C. (2011) Statistical Compilation of the ICT Sector and Policy Analysis in Cameroon. Montreal: Orbicom International Secretariat.

OECD (1999) Managing National Innovation Systems. Paris: OECD.

O'Farrell, C. (ed) (2003) Revisiting the Magic Box: Case Studies in Local Appropriation of Information and Communication Technologies (ICTs). Rome: Food and Agricultural Organisation (FAO).

Poncet, J., Kuper, M. and Chiche, J. (2010) Wandering off the paths of planned innovation. Agricultural Systems 103(4): 171-179.

Prahalad, C.K. (2009) The Fortune at the Bottom of the Pyramid: Eradicating Poverty Through Profits, $5^{\text {th }}$ anniversary ed. Philadelphia, PA: Wharton School Publishing.

Ratanawaraha, A. (2012) City Innovation Systems in Southeast Asia. Paper presented at $10^{\text {th }}$ Globelics International Conference, 9-11 November, Hangzhou.

Schofield, J.W. (2002) Increasing the Generalizability of Qualitative Research. In: M.B. Miles and A.M. Huberman (eds) The Qualitative Researcher's Companion. Thousand Oaks, CA: Sage Publications, pp. 171-203.

Shirley, M.M. (2008) Institutions and Development. In: C. Menard and M.M. Shirley (eds) Handbook of New Institutional Economics. Berlin: Springer, pp. 611-638.

Simanis, E. and Hart, S. (2009) Innovation from the inside out. MIT Sloan Management Review 50(4): 78-86.

Stewart, J. and Hyysalo, S. (2008) Intermediaries, users and social learning in technological innovation. International Journal of Innovation Management 12(3): 295-325.

Utz, A. and Dahlman, C. (2007) Promoting Inclusive Innovation. In: M.A. Dutz (ed)

Unleashing India's Innovation: Toward Sustainable and Inclusive Growth. Washington, DC: World Bank, pp. 105-129.

Winch, G.M. and Courtney, R. (2007) The organization of innovation brokers: An international review. Technology Analysis and Strategic Management 19(6): 747-763.

Yin, R.K. (1994) Case Study Research: Design and Methods. Thousand Oaks, CA: Sage Publications.

\footnotetext{
' During research work in a single mobile trading area in Nairobi - albeit a particularly dense one - a street-by-street survey found more than 2,000 micro-enterprises connected to either mobile phone sales or demand-side services. Such figures are only indicative: informal enterprises are often missed in surveys, and it is not possible to extrapolate nationally from this single urban cluster. However, it is estimated that phone and airtime sales, public payphone operation, and related activities employ 157,000 full-time equivalent people in Kenya (GSMA 2011); a figure consistent with findings in other African nations of around 10 informal sector phone-related jobs for every 1 formal sector job (Nzepa et al., 2011).

"Figures not substantially different from the proportion of the Kenyan population that each of these groups represents.

iii The policy was not perfect: local council police still sometimes tried to enforce other licensing rules - such as fire safety or signage - in order to extract bribes. And it was reported by respondents that licensing rules were poorly implemented outside Kenya's main cities.
} 